\title{
The risks of sociolinguistic crossing and cross-overs: A retrospective from apartheid South Africa
}

Rajend Mesthrie

Department of English Language and Literature, University of Cape Town, Private Bag X3, Rondebosch 7701, South Africa

E-mail: rajm@uct.ac.za

\section{Introduction}

This article discusses the reception of a new accent within a community, based on the norms of a former out-group. Today, 15 years into a non-racial democracy in South Africa crossover accents are unremarkable, as new peer groups and social networks have evolved amongst young middle-class students. Young Black people (including Indians and Coloureds) are to varying degrees accommodating to prestige norms formerly associated with White middleclass speakers. The article recounts an incident from the early to mid-1980s that shows the complexities of adopting a "cross-over" accent. A young female student of Indian South African background speaking to a member of the same community in an institutional context using a prestige "White" accent found her request for assistance being rejected. The incident is examined in terms of findings in intercultural communication and sociolinguistic accommodation.

The main focus of the field of intercultural communication is the potentially diverse cultural norms that are associated with different languages or ways of speaking the same language. The former involves an implicit contrast between the structure and pragmatics of two languages - e.g. Kaschula \& Anthonissen (1995) on Xhosa and English. The experience of 
bilinguals is the most likely site for this kind of work. The bilingual speaker may (consciously or not) transfer certain cultural practices associated with the first language (L1) into the second language (L2) (e.g. kinship terms; pronouns of respect etc.) by way of neologisms, borrowings (or retentions), calques, hybrid forms and the like. Another site of study is the practice of translators as they struggle to render a text into a culturally appropriate form from one language into another. Intercultural studies of (L1) varieties within the same language are not uncommon. These studies tend to focus on the contrasts between a dominant (standard) dialect and an emerging L2 variety, the latter representing a carryover from the L1 of speakers of a less powerful or prestigious variety in the society. Gumperz's (1982:172-186) account of Indian and Pakistani English speakers in England examines the L2 English norms of speakers whose mother tongues include languages like Gujarati, Panjabi and Hindi-Urdu. Likewise, Chick's (1995) study of the interactional norms underlying Zulu English and White South African English (henceforth WSAE) involves interaction between a lower status L2 variety and the dominant L1 variety on the Durban campus of the (then) University of Natal. ${ }^{1}$ The contrasting pragmatic norms associated with Zulu English and WSAE lead to occasional cultural stereotyping and misunderstanding. It should be emphasised that in the majority of such studies, power inequalities of one sort or another precede and, in fact, underlie the intercultural miscommunication.

In this paper I wish to change the focus slightly to examine the dynamic between members of the same community expected (in the unmarked case) to use a version of the same dialect, even though there is an alternative resource provided by the norms of the standard (or other prestige) variety in the wider society. This dynamic involves ideological uncertainties and contestations around an ethnic or community-oriented variety and a newly-acquired prestige variety. The key sociolinguistic frameworks of relevance, as I show later, are those of Giles (see Giles \& Powesland 1975; Giles 2001) on speech accommodation, Myers-Scotton's (1993) markedness model of code switching and Blommaert's work (e.g. 1999) on ideology in pragmatics. 


\section{Some relevant frameworks for understanding speech divergence}

In terms of Giles' accommodation theory speakers accommodate their speech to gain their addressee's approval and foster and maintain good relations. Speakers adjust their style of speech (in accent, speech rate, syntax etc.) in convergence to that of their interlocutor. However, the opposite - divergence - is also possible, in which a speaker emphasises linguistic differences from the interlocutor to maintain social distance. Bell's (1984) concept of audience design, which developed within the framework of variationist sociolinguistics, rather than social psychology, is in many ways an elaboration of accommodation theory. Bell proposed that speakers' style choices reflect a response to the audience. In the special case where the audience and interlocutor are one and the same, the two frameworks (speech accommodation and audience design) coincide. In monologues, where the audience is imagined, accommodation to this audience may still take place, as in Coupland's (2001) study of the style choices of a Cardiff deejay. In all other cases, Bell argues that the audience (e.g. other addressees in the group, ratified "auditors", overhearers etc.) also play a role in constraining the speech style of a speaker.

Convergence and divergence also play a role in Myers-Scotton's (1993) markedness model, which is sometimes questioned regarding its purported universality (see the essays in Auer 1998), though it appears to be particularly apt in the analysis of interactions in multilingual postcolonial contexts, especially in Africa. The basic tenets of the model are well known and only a broad overview is necessary here: the idea of a balance between rights and obligations (henceforth $\mathrm{R} / \mathrm{O}$ ) that underlie speech acts; the use of an unmarked code in interactions in which one wishes to affirm the R/O associated with a prevailing speech act; a marked choice to change the R/O etc. One particular type of code-switching is of relevance to this paper: the use of a sequence of unmarked choices to strike up a favourable relationship in events of a transactional (rather than conversational) nature. I present a well-known example from Myers-Scotton's studies in Kenya, followed by two South African examples which reinforce the analysis. Thereafter I show an example of the principle in reverse, leading to a failed transaction between two Indian South African English (ISAE) speakers. Myers-Scotton (1992:168-169) describes an interaction between a Luyia-speaking visitor entering a Nairobi company's head office and the security guard. Their initial discussion is in KiSwahili, the 
unmarked choice for transactions between strangers. But when the guard decides the visitor must be Luyia, he switches to a Luyia variety, since he himself is Luyia. This switch shows an unmarked choice in this context; the R/O balance changes away from that involving company security guard and visitor (two strangers) to the possibilities of community cooperation between ethnic "kin".

A similar account involving speakers of African languages in Gauteng province, South Africa, is given by Herbert (1997), confirming that an unmarked lingua franca may be replaced by a speaker's mother tongue to narrow the social distance between interactants. Speaker A begins in North Sotho, the unmarked code in Pretoria, trying to get access into a department store which is about to close for the day. He is obstructed by B, the security guard. Guessing B to be Xhosa (from his North Sotho accent), A switches to Xhosa and English. The former symbolises community-based obligations, the latter is a reminder of the status of young educated people, though A softens it by emphasising respect by the use of the term "daddy". The result is a favourable transaction for A as B switches to Xhosa with the cooperative injunction, khawuleza ugqithe 'pass quickly'. The switch to Xhosa by the guard shows an acceptance of the obligations ensuing from a shared Xhosa background.

A third example that one occasionally hears from South Africans of diverse origins is the use of an African language by speakers whose mother tongue is English or Afrikaans to extract a favour. Webb (2002:137) gives such a personal account in his book Language in South Africa, aiming to stress the value of African language interaction. After being flagged down for speeding, he negotiates with the traffic officer in what would be a marked choice between an Afrikaans or English speaker and a Black South African - Zulu.

I spoke Zulu to the traffic officer, which I had acquired as a child. My fine was going to be heavy, so I asked him whether we couldn't make some sort of plan. He said: What sort of plan? I said, well, anything - like ignoring one of my offences? He thought for a moment and then said "you can go", with no further prosecution.

Webb shows the same kind of linguistic opportunism as the Xhosa speaker cited above. By switching to Zulu, a language Webb is not expected to know, he is able to summon the rights 
and obligations associated with "typical" speakers of Zulu (in this context anyway). By not electing for Afrikaans or English he also symbolically diminishes his own status as a member of the White elite. And he escapes without a fine.

Finally, Rampton's (1995) work on crossing is of relevance to this article: a speaker's use of a variety or parts of a variety (e.g. greetings and exclamations) associated with a social group that the speaker does not belong to. Rampton (1995) exemplified the use of Panjabi or Creole by a White, largely monolingual speaker, as a means of contesting broader patterns of race division and hierarchy in the society. Crossing appears to be an example of a temporary challenging of borders, rather than becoming a habitual bilingual. It is a marked effect, rather than a linguistic norm.

\section{Inappropriate divergence: a cameo from apartheid South Africa}

The interaction I focus on in this paper reinforces the framework offered by Giles \& Powesland (1975), Bell (1984) and Myers-Scotton (1993) by showing a different outcome when a speaker fails to take the opportunity to switch codes, and stresses divergence rather than convergence in a situation where the latter was preferable. The interaction to be analysed is a brief one that I witnessed in 1983 between a visiting student and an English lecturer at the (then) University of Durban-Westville (henceforth $U D W$ ). ${ }^{2}$ This was a university established in the 1960s exclusively for Indians, under apartheid education. By 1983 the campus was starting to desegregate, but still had a clear Indian majority, in its student body, clerical staff and workers. The lecturing staff had Whites and Indians in roughly equal proportions. A young male lecturer (henceforth " $A$ ") was typing up materials in the department's secretarial office on an electric typewriter, which was at that time the zenith of technology. This was the only such typewriter in the department, which staff members could use only if it was not required by the secretary. On that particular day she was off sick, and $A$ had intended to spend the morning typing up a report. A necessary ingredient of the "context of situation" was that far from working uninterruptedly as he had intended, $A$ had to face a number of student enquiries and requests. Some of these were routine and responded to hastily; others which were less routine were postponed till the return of the secretary. Almost all students were ISAE speakers (given the dynamics of apartheid society and tertiary education), as $A$ himself was - deploying a style that veered between informal to consultative, depending on his 
relationship with individual students and the needs of the situation (see Joos 1959; Mesthrie, Swann, Deumert \& Leap 2000:96-97). At that time, with segregation in housing and education still a reality, ISAE was a "focussed" variety in Natal (now KwaZulu-Natal), being used in a range of situations, including education. Different sub-varieties could therefore be deployed to mark solidarity (mesolect), intimacy (basilect-mesolect) and status (acrolect) within the community, depending on factors like context and speaker-background (see Mesthrie 1992:34-70). More formal styles converging with the acrolect were, and still are, appropriate in educational and other speechmaking contexts.

In the early 1980s a new phenomenon was emerging with the decline of "petty apartheid". That is, though the laws of "grand apartheid" were still in force till 1994, some relaxing of restrictions had already occurred in respect of dining at restaurants, staying at certain ("international") hotels and attendance at private schools and universities. White schools and universities began taking in small numbers of "non-White" students. ${ }^{3}$ For the first time since 1948 ISAE speakers could come into contact at a relatively young age with speakers of other varieties of English, especially WSAE natively and start to form social networks along nonracial lines. The 1980s saw the first trickle of speakers who started to acquire an accent associated with "Respectable" WSAE (see Lanham \& Macdonald 1979) rather than another ethnically-marked variety. ${ }^{4}$ The period also saw the acquisition of this variety as a second dialect by some speakers to use in accommodation to WSAE speakers or as a status marker. The "non-intercultural event" reported on in this study involved a female student with such a background, (henceforth " $B$ "). She had had a conventional segregated education at an Indian school in Durban in the 1970s, before gaining admittance to the Durban campus of the University of Natal (henceforth $U N D$ ), which had a large majority of White students at the time. The interaction, which was of a transactional rather than interpersonal nature was as follows. Speaker $A$ tries not to acknowledge speaker $B$ as he continues typing. Speaker $B$ tries to attract his attention and eventually does. She explains in a strong Respectable WSAE accent that she is a UND student who wishes to attend a particular lecture of the second year English class at UDW. She mentions the lecturer and the topic, and wishes to ascertain the venue. It turns out that this is something of a personal initiative on her part, not suggested by her UND lecturers who would have expected her to work at the text herself. The lecture is not, in fact, open to the public. It is also clear that $B$ takes $A$ to be the secretary of the department. This in itself is no slight, as $A$ had previously been mistaken as technical 
department assistant (as he frequently helped other lecturers operate the Roneo copying machine in the corridors in full view of passing passengers on the lift). This is something of a departmental joke. $A$ explains that he is not the secretary and that he does not have quick access to the information required. Where had she received the information about the topic of the lecture from in the first place? The student mentions her uncle, a lecturer in the Commerce faculty, who regularly takes tea with Arts faculty staff and hence had spoken to the lecturer who was to give the relevant lecture. She gives his name in full, Rati Raidoo (a pseudonym, which nevertheless preserves all the phonetic points of relevance). She pronounces the name

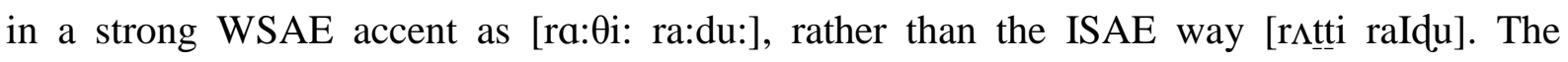
segmental differences between the two versions are stark, with the WSAE accent showing the following:

(a) lowering and lengthening of $[\Lambda]$ to $[\mathrm{a}:]$;

(b) de-geminating the medial [tt $]$;

(c) turning the dental stop $[\mathrm{t}]$ to the fricative $[\theta]$;

(d) monophthongising [aI] to [a: $]^{5}$;

(e) avoiding the weak retroflexion on [d] in ISAE.

There are also major non-segmental differences of pitch, intonation and articulatory setting, but as the incident was observed, not recorded, it is not possible to give further details. At this stage $A$ brusquely says that he is busy, and asks $B$ to go upstairs to get the information from the course convenor instead, although he was not certain if the convenor was in.

I later commented on $A$ 's uncharacteristic rudeness to the visitor. $A$ excused himself on the grounds of being busy, facing deadlines, the lack of back-up secretarial support in a large department in which the secretary was often ill, and having to pay the penalty for being one of the few staff members actually present in the department for long periods of the day. But the criticism was correct, as there were other factors at work. Firstly, it is necessary to discount the gender and status differences, as they do not appear to apply to other interactions between $A$ and his students. If anything, he errs on the side of being more helpful to female than male students; and female than male staff. Likewise, several years of student evaluations of his teaching gave no evidence of an unnecessary recourse to power differentials between lecturer 
and students. He was regarded as generally rather easy going and helpful. So why the unhelpfulness in this case? Negative face needs (Brown \& Levinson 1987) do come into play since $A$ needed to carry out his work without distraction. It might be argued that these needs can be attained better with a student from a "foreign" campus, rather than with a student from within the department, whom he might have to "face" regularly. The dynamic between the two universities is another factor to be considered. It was a truism that the older, White English-medium universities were better resourced, attracted better qualified staff (on the whole) and offered better education than the universities created for people of colour by the apartheid government in the 1960s. But such rivalry was not a serious factor in relations between English department staff from the two universities; and having been the occasional recipient of help from scholars from a number of disciplines, there was no aversion in principle on $A$ 's part to helping out an occasional visiting student.

\section{An analysis of pragmatic failure in inappropriate divergence}

A's unhelpfulness boiled down to three issues: (a) actually being busy and frustrated in his efforts to get things done (being irritable is how $B$ would probably have seen it); (b) the "presentation of self" by $B$, especially in the choice of code for the interaction at hand; and (c) a clash of dialect ideologies.

It is the latter issue that I dwell on in the rest of the paper. $B$ starts off introducing herself as a visitor from the neighbouring White university in a WSAE accent that showed no traces of an Indian substrate. But given her personal background it was clear that she was a speaker of ISAE, prior to going to university. That she calls upon the cultural capital of WSAE as an opening gambit is perhaps understandable. In this way she establishes herself as not the average UDW student, her accent carries marks of "distinction" (in the sense of difference, as well as superiority, on the linguistic market - see Bourdieu 1991:66-102). But when she explains the motives for her visit she misses an opportunity for strategic code switching to ISAE. In effect, she is asking for a favour in wishing to use the resources of the "Indian" campus to help her succeed in her studies at the "White" campus. This is in effect a weak appeal to ethnic solidarity; most UND students of the time would not have thought of turning to a UDW lecture to gain additional information to help them in their studies. The appeal to solidarity is strengthened by mentioning the relative who suggested the visit in the first place. 
That he is an uncle is a reminder of the importance of kinship bonds, and the relation between males and nieces can be particularly significant in the South Indian culture to which the "Raidoos" belong. That he is a lecturer in the Commerce faculty who knows members of the English staff appeals further to staff solidarity. What was odd was that in making these content moves $B$ did not make the appropriate, concomitant linguistic shifts. Her discussion continued in Respectable WSAE and diverged even further when she pronounced the name of the uncle: [raidu] as [ra:du]. Some Anglicisation of the pronunciation of Indian names was already evident in the 1980s; these were minor ones relating largely to the fronting of low back $[\Lambda]$ and [a:]; thus [sændzi:v] rather than [sındzi:v] for Sanjeev, and the variable ISAE pronunciation of Gandhi (as [gændi:] or [ga:ndhi:]). However, the wholesale transformation of an older relative's name when speaking to another ISAE speaker is code divergence in the extreme. It counts as a form of hypercorrection: overuse (or overgeneralisation) of a form from an external prestige dialect. Bourdieu's (1991:62-63) observation that such (lower middle-class) hypercorrections indicate a class divided against itself is perhaps relevant here. The mismatch between the content of the interaction, which seemed mindful of ethnic nuances, and the form of the utterances are what were disconcerting to $A$. $B$ was at one and the same time appealing to her kinship with her uncle-lecturer; yet distancing herself from any vestige of kinship by giving his name a full WSAE pronunciation.

The transaction can be cast in more general interactional terms using the frameworks provided by Myers-Scotton (1993) and Giles \& Powesland (1975). In Giles' terms speaker $B$ starts off with and maintains a divergent linguistic stance. To the interlocutor this suggests a status differential and social distance. It is unclear whether speaker $B$ really had intended this effect. It is possible that she was being defensive since her request was an unusual one, and thereby chose and maintained what counted as an outgroup code even for her. Bell's (2005) account of initiative shifts is particularly relevant here:

Initiative shifts are in essence 'referee design', by which the linguistic features associated with a group can be used to express affiliation with that group. They focus on an absent reference group rather than the present audience. This typically occurs in the performance of a language or variety other than one's own (cf. Rampton's (1995) concept of 'crossing'). 
In relation to Myers-Scotton's model, $B$ opens in Respectable WSAE thereby setting the initial frame as one involving the rights of speakers of that variety (the absent reference group referred to by Bell). Whereas a White speaker would have had few options but to use their unmarked dialect norms (Respectable WSAE for most university students), B was (unconsciously) eschewing the choice of ISAE, and asserting the rights associated with Whites (or White students) in apartheid South Africa. This included the right to be treated seriously as a member of the most powerful group in the country; it also suggested privilege, confidence and "entitlement". It is also possible that a particular gender effect is involved. White females have a greater degree of freedom from kinship and community bonds than Indian females in South Africa (Meer 1969:60-74). Perhaps $B$ was trying to assert some of this freedom too. However, as discussed above, the next content move was to ask for a specific favour that effectively cancelled out these rights; and $B$ moved into a mode of reminding $A$ of possible obligations to help the relative of a colleague. This is a move away from status considerations to those of solidarity. $B$ missed the opportunity to switch to the appropriate code (ISAE), not only because $A$ was a speaker of this variety, but because she herself would have been sending a reinforcing signal of her needs, not just her rights. The content of her interaction stressed her needs and A's obligations but the code choice continued to stress her rights as a member of an out-group university. In later pronouncing her uncle's name with a WSAE accent, she strengthened this anomaly, progressing from a marked to an even more marked move. At the risk of repetition, in apartheid South Africa when ethnic solidarity was an important factor (for economic and political reasons) $B$ asks for a favour from ethnic kin, using the code associated with power, which does not need favours.

Myers-Scotton (1993) has proposed that all speakers are rational actors insofar as they calculate the consequences of their code choices, where there are options. Critics of the model (e.g. Blommaert 1999:171-174; Crawhall 1993) propose that most choices are not wilful, but determined by the ideologies pertaining to the current social conditions. In Myers-Scotton's (1993) East Africa work this is largely a colonial / postcolonial dynamic still being played out in language. The present study proposes that speakers may make infelicitous choices through lack of experience. I have characterised $B$ 's choice as hypercorrective: in other words, having acquired a new code, she overuses it. She had still (in 1983) to constrain her repertoire of codes according to the context, and in accordance with the speech acts she is engaging in with 
specific interlocutors. Myers-Scotton's model is not incompatible with a learning component: speakers presumably master (and even reproduce) the prevailing R/O balance between codes by trial and error. However, one has to learn fast in order to perform felicitous speech acts in a range of situations. Given the stimulus of large-scale societal change (for example, the sort that has occurred in South Africa since 1994) rights and obligations may be contested, changed or created afresh. There must therefore be some overlap (and therefore ambiguity) between $\mathrm{R} / \mathrm{O}$ balances of different speech choices in societies in transition.

The intercultural implications of this non-intercultural encounter may be pondered upon. Firstly, whilst overtly prestigious in many situations including informal programmes in the broadcast media, the prestige dialect (Respectable WSAE) is not itself unmarked in all situations. Secondly, varieties identified as ethnolects in South Africa (Black SAE, ISAE etc.) and beyond are not lacking in what Labov (1972:110-121) characterised as "covert prestige"; and may additionally themselves have prestige sub-varieties. For example, in the ISAE community, formal speechmaking at weddings, funerals and the like is taken as more sincere if it draws on community norms, rather than too obviously WSAE or other norms (e.g. ISAE Christian preachers influenced by U.S. English norms). From the informal reactions I have encountered to ISAE speakers on the radio and in university lecture halls, it seems that too obviously an ISAE accent and too obviously a WSAE accent are equally disfavoured by Indian listeners. This might not apply to television, where a distinct newsreader's style prevails, across ethnic boundaries (and the context is not deemed to be an ethnic one, anyway). All sociolects are socially diagnostic; there is no neutral "correct" variety as prescriptivists try to make out. No one variety is judged as unambiguously appropriate in all situations.

\section{Conclusion - Crossing-over 25 years on}

It has to be stressed that the intercultural encounter focussed on in this paper would be less noticeable today, 15 years after the arrival of a more open, post-apartheid society and over 25 years since this early incident of "crossing over" was noted. The ideologies associated with varieties, especially with Respectable WSAE have become more fluid. A younger version of $B$ today might not even command ISAE well enough to use it in a public setting, if her social networks revolve around friends from private schools or other schools in which WSAE 
prevails. The rights and obligations attached to Respectable WSAE may well be changing to encompass a less racialised reality as more and more Black, "Coloured" and Indian middleclass males and (especially, I think) females adopt the variety. This is 'crossing over' rather than just 'crossing' in Rampton's (1995) sense of the playful use of styles and varieties one was not traditionally associated with or even fully acquainted with. Speaker $B$ would therefore probably encounter a less negative response today. ${ }^{6}$ Or she might, by virtue of experience, have learned to strategically use more than one code according to the context (rather like the other speakers in the Myers-Scotton and Herbert studies cited above), or show some convergence at least. Le Page \& Tabouret-Keller's (1985:14) dictum that language involves a series of acts of identity in which people both reveal their personal identity as well as their ongoing quests for social roles applies in the more diffuse, post-apartheid, young peoples' linguistic order. That is, a language is a dynamic entity, which is partly inherited and partly being made (or remade) by its speakers.

\section{Notes}

1. It is perhaps still necessary to emphasise that the use of "colour" terms in this paper is not meant to give credence to the old style of racial classification: however, South African English still shows a primary division by ethnicity, though other parameters like L1 vs L2 and class are becoming increasingly salient. In particular, we may be witnessing a new, relatively de-ethnicised English being born amongst middle-class youngsters in post-apartheid multiracial schools (Da Silva 2007; Mesthrie 2008).

2. Now known as the Westville campus of the University of KwaZulu-Natal, after the merger of universities in the province under post-apartheid education.

3. The apartheid laws enforced a racial policy in universities since the 1950s. African, "Coloured" and Indian students had to then apply for special permission to attend such "White" universities. Permission was granted only if they intended to study a subject not on offer at an "ethnic" university and if they were not seen as opponents of apartheid.

4. $\quad$ "Respectable" is a term used by Lanham \& Macdonald (1979) for a local prestige variety of SAE that did not accord with the RP-oriented norms of upper middle-class "Conservative SAE".

5. This feature was particularly characteristic of WSAE (see Lanham \& Macdonald 1979). 
6. A did check a few days later with Rati Raidoo whether his niece had located the lecture venue and whether she had benefited from the lecture. Both answers were affirmative. A also tendered an apology for not having being particularly helpful. Regretfully, I was unable to contact speaker $B$, to gauge her reaction to this "nonintercultural event".

\section{References}

Auer, P. (ed.) 1998. Code switching in Conversation: Language, Interaction and Identity. London: Routledge.

Bell, A. 1984. Speech Style as Audience Design. Language in Society 13(2): 145-204.

Bell, A. 2005. Speech Accommodation theory and audience design. In J.K. Brown (ed.) The Pergamon Encyclopedia of Language and Linguistics, $2^{\text {nd }}$ ed. Oxford: Elsevier, vol 11: $648-651$.

Blommaert, J. 1999. State Ideology and Language in Tanzania. Cologne: Rüdiger Köppe Verlag.

Bourdieu, P. 1991. Language and Symbolic Power, ed. J.B. Thompson, trans. G. Raymond and M. Adamson. Cambridge, MA.: Harvard University Press.

Brown, P. and S. Levinson. 1987. Politeness: some Universals in Language Usage. Revised Edition. Studies in Interactional Sociolinguistics 4. Cambridge: Cambridge University Press.

Chick, J.K. 1995. Interactional sociolinguistics and intercultural communication in South Africa. In R. Mesthrie (ed.) Language and Social History: Studies in South African Sociolinguistics. Cape Town: David Philip. pp. 230-241.

Coupland, N. 2001. Dialect stylisation in radio talk. Language in Society 30: 345-376.

Crawhall, N. 1993. A Critique of Code-switching with special reference to Harare. Unpublished MPhil dissertation, University of Zimbabwe.

Da Silva, A. 2007. South African English: a Sociolinguistic Analysis of an Emerging Variety. Ph.D. thesis, University of the Witwatersrand.

Giles, H. 2001. Speech Accommodation. In R. Mesthrie (ed.) Concise Encyclopedia of Sociolinguistics. Amsterdam: Elsevier. pp. 193-197.

Giles, H. \& P. Powesland. 1975. Speech Style and Social Evaluation. London: Academic Press. 
Gumperz, J.J. 1982. Discourse Strategies. Studies in Interactional Sociolinguistics 1. Cambridge: Cambridge University Press.

Herbert, R.K. 1997. The meaning of language choices in South Africa. In R.K. Herbert (ed.) African Linguistics at the Crossroads: Papers from Kwaluseni. Cologne: Rüdiger Köppe Verlag. pp. 395-416.

Joos, M. 1959. The isolation of styles. Georgetown University Monograph Series on Languages and Linguistics 12: 107-13.

Kaschula, R. \& C. Anthonissen. 1995. Cross Cultural Communication in South Africa. Johannesburg: Witwatersrand University Press.

Labov, W. 1972. Sociolinguistic Patterns. Philadelphia: University of Pennsylvania Press.

Lanham, L.W. \& C. Macdonald. 1979. The Standard in South African English and its Social History. Heidelberg: Julius Groos Verlag.

Le Page, R. \& A. Tabouret-Keller. 1985. Acts of Identity - Creole-based Approaches to Language and Ethnicity. Cambridge: Cambridge University Press.

Meer, F. 1969. Portrait of Indian South Africans. Durban: Avon House.

Mesthrie, R. 1992. English in Language Shift - the History, Structure and Sociolinguistics of South African Indian English. Cambridge: Cambridge University Press.

Mesthrie, R. 2008. Death of the mother tongue: is English a glottophagic language in South Africa? English Today 24(2):13-19.

Mesthrie, R., J. Swann, A. Deumert \& W. Leap. 2000. Introducing Sociolinguistics. Edinburgh: Edinburgh University Press.

Myers-Scotton, C. 1992. Codeswitching in Africa - a model of the social functions of code selection. In R.K. Herbert (ed.) Sociolinguistics in Africa. Johannesburg: Witwatersrand University press. pp. 165-180.

Myers-Scotton, C. 1993. Social Motivations for Codeswitching - Evidence from Africa. Oxford: Clarendon.

Rampton, B. 1995. Crossing - Language and Ethnicity amongst Adolescents. London: Longman.

Webb, V. 2002. Language in South Africa. Amsterdam: Benjamins. 